XXVI. Monograph of the Class Myriapoda, Order Chilopoda; with Observations on the General Arrangement of the Articulata. By George Newport, Esq., Fellow of the Royal College of Surgeons, President of the Entomological Society, \&c. Communicated by the Secretary.

Read March 19th, April 2nd and 16th, 1844.

IT has been well remarked by Gervais, in his essay on the Myriapoda, that of all the Articulata this class has been less carefully studied than any other. So few and general are the details respecting the Myriapoda, even in the works of those who have paid most attention to them, that it has been almost impossible to identify any one species from the descriptions that have heretofore been given. The species formerly described by Leach, few as they were, have from this circumstance remained up to the present time almost entirely unknown to the continental naturalists, and, as recently remarked by Brandt, it still remains for the English naturalists to supply these deficiencies. Many new species have lately been described by Brandt himself; and the multitude of specimens that are nuw brought to this country from every part of the world, prove that the number of species that exist is very considerable, although their distinct identification is exceedingly difficult, owing to their great similarity of form, and often of colour; and also to the great variableness in the markings and colour in the same species. It was the total inability I experienced from these causes to identify specimens that I wished to examine anatomically, that led me to attempt to characterise what seemed to be new to science, and to re-exanine those formerly described by Leach, and still preserved in the cabinets of the British Museum. In this endeavour my views have been most kindly forwarded by my friend the Rev. F. W. Hope, who in the most handsome manner placed his whole collection at my entire command, for the purpose both of internal anatomical investigation of structure as well as for the description of species. I have also to acknowledge a like 
unrestricted access to the cabinets in the British Museum, through the liberality of the head of the department, J. E. Gray, Esq., to that of the Museum of the gentlemen of the United Service, of the Zoological Society, and also to the Linnean and Banksian cabinets. These means of research have enabled me not only to identify many of the species originally described by Linnæus and Dr. Leach, and to add considerably to the number of new species, but also to deduce conclusions respecting the whole class. Part of these results, which refer to the Chilopoda, I now propose to do myself the honour of submitting to the Linnean Society.

The Myriapoda may be characterized as an osculant class of invertebrated apterous animals, that typify, as a permanent condition, the transitory form of the larva state of insects. One division of these animals has relation to the rapacious and active Arachnida, and the other to the strong-bodied, lignivorous Crustacea. In each division the head of the Myriapod is distinct from the body, and is furnished with a pair of antennæ; and the body is elongated, and divided into many uniform, moveable segments, of which, in the adult state, there are usually more than fifteen, and never less than twelve. Each of these moveable segments gives origin to one, and sometimes to two pairs of legs. The Myriapoda respire atmospheric air by means of spiracles and ramified tracheæ. They leave the ovum in an incompletely developed embryonic form, and afterwards undergo many changes of tegument or pseudometamorphoses, at each of which the body acquires an addition of segments and legs, until the animal bas obtained its adult number; after which it merely continues to increase in size at each change.

Linnæus and the older naturalists arranged the Myriapoda with apterous insects, and even now* they are regarded by some as constituting only a division of the great class Insecta. But although they approach very closely in their general appearance, internal anatomy and modes of life to the larva state of insects, they nevertheless differ quite as much as the Crustacea and Arachnida, which almost every modern naturalist has separated from the true Hexapods. The manner in which the Myriapoda acquire their perfect state, by an extension of, and an addition to, rather than by a shortening of the body, is so dissimilar to the changes in insects that it fully entitles them to be

\section{* Brandt.}


considered as a distinct class, notwithstanding the opinions that have recently been urged by some naturalists in regard to their supposed identity with true insects.

The place assigned to the Myriapoda by Linnæus was at the end of his order Aptera, immediately before the true Vermes. This arrangement is in full accordance with the facts now ascertained respecting their metamorphoses and mode of growth, which indicate their close affinity to the latter class. Fabricius allied them to some of the true Crustaceans, the Oniscidoe or Woodlice, with which he formed them into the order Mitosata, and interposed them between his order Odonata and the Arachnida, a situation, assuredly, as unnatural as the objects themselves are dissimilar in habits and structure. Lamarck arranged them in his third class of invertebrated animals with the Arachnida, and associated them with some true Hexapods, the Thysanoura, to form his second order, Arachnides Antennistes; thus collecting together in the same group, as Gervais has well remarked*, animals that belong to three very distinct classes. Our own countryman, Dr. Leach $\dagger$, was the first naturalist that appears to have carefully examined these animals, which, following to a certain extent the views of Fabricius, he grouped together as a distinct class by the name of Myriapoda. But although Leach avoided the error of Fabricius in approximating them to the winged insects, Libellulida, the Odonata, and connected them more naturally, on the one hand, with the Crustacea, by means of the genera Armadillo and Glomeris, he united them, on the other, to the Arachnida by means of the Geophilidce and Nymphons, and thus placed them between two classes, the Crustacea and Arachnida, which certainly are more nearly related to each other than to the Myriapoda.

The class Myriapoda, as established by Leach, has been adopted by many eminent naturalists, but there still exists as great a diversity of opinion in regard to its relation to the other classes as before its separate establishment. De Blainville first connected the Myriapoda with the Annelida by means of the bristly genera, the Annelida errantia; but subsequently remarked a closer connexion between the two classes in the singular Iuliform genus Peripatus, Guild., which genus he afterwards established as a separate class. Latreille

* Annales des Sciences Naturelles, Janvier 1837.

† Linnean Transactions, vol. xi. p. 376, 1814.

voL. XIX.

$2 \mathrm{~N}$ 
regarded the Myriapoda as closely connected with the Thysanoura*, to which he joined them by means of the genus Forbicina, Geoff.; while Strauss agrees with De Blainville in opinion respecting the affinity which exists between the Myriapoda and Annelidat, but conceives the transition to be found in Pollyxenus on the one hand, and Eunice and its affinities on the other ; and he has also remarked, with Latreille and Dugès, that the Myriapoda have some close relations with the Thysanoura. A more recent authority, M. Brandt炗, who has paid very close attention to these animals, regards them as connected directly with true insects ; and in this opinion he is supported, as he remarks, by the Committee appointed to examine a work recently presented by $M$. Gervais to the Institute of France.

After an attentive examination of the Myriapoda, as compared with other Articulata, I have been unable entirely to adopt the views of any one of the distinguished naturalists above noticed, either in regard to the situation which they ought to occupy in the arrangement of the Invertebrata, or to the affinities by which they are connected with the other classes. They certainly have many close relations to the larva state of true insects in the elongated form of the body, in their mode of respiration, in the structure of the organs of circulation and nutrition, and also in the arrangement of their nervous system; but they differ from them entirely in their mode of growth and development.

The Myriapoda, as just stated, acquire a periodical addition of segments and legs, with their separate ganglia, nerves and other structures. This addition of new parts, at each change of tegument, takes place in all the Myriapoda up to a certain period of their growth, which period varies in different genera. But this addition of parts never occurs in Insects, even in the lowest forms of the class, or even in their earliest stages, after leaving the ovum. Every entomologist is aware that when an insect bursts from the egg it is furnished with the whole number of segments and legs it is ever to possess; and in no instance does the number of segments exceed fifteen. The usual number, thirteen, as naturalists are well aware, is very rarely exceeded; although

* Nouvelles Annales du Muséum, i. p. 175.

+ Considérations Générales sur l'Anatomie des Animaux articulés, 4to, 1828, p. 16.

† Recueil de Mémoires relatifs à l'ordre des Insectes Myriapodes, 1841. 
in some of the Hymenoptera Mr. Westwood* and myself $\dagger$ have observed fifteen. During the changes of the insect this number is gradually reduced by the aggregation and anchylosis of some of the segments to form particular divisions or regions of the body, in the construction of which some of the segments become enlarged, and others are atrophied or almost obliterated. In the Myriapoda, on the contrary, the young animal invariably comes from the ovum with its smallest number of segments, and in most of the genera this seldom exceeds nine; although before the Myriapod has arrived at its full growth, it acquires, in some species, nearly eight times the original number ; a definite number of new segments being constantly in the course of formation between the antepenultimate and penultimate segments of the body. This is the great characteristic of the class, which distinguishes the Myriapoda from Insecta, Arachnida and Crustacea, and approximates them to the Annelida, in which a similar addition of parts takes place. The Myriapoda are also distinguished from Insects by a permanent anatomical character, the number of segments and legs in the adult animal. There are never fewer than twelve segments and eleven pairs of legs in any genus of Myriapoda. In some genera the latter even amount to one hundred and sixty; while no insect, even in the larva state, has more than eight pairs, five of which are rudimentary, and disappear as soon as the four anterior segments have acquired their full growth, and the insect undergoes its metamorphosis, when its legs are reduced to three pairs, and the insect passes into a higher state of development. These are the considerations which have led me, with Leach, Latreille, and others, in opposition to the bigh authority of M. Brandt, to separate the Myriapoda from the true Insects, and to place them as a class immediately before the Annelida.

It bas been customary with most zoologists to make the organs of nutrition the basis of classification in the Invertebrata, because these are more distinctly marked in the lowest organized species. This is the view adopted by Cuvier, Owen, and some other anatomists and zoologists. But although I hesitate to differ from these high authorities, I cannot help regarding the organs of

* Transactions of the Entomological Society of London, vol. ii. p. 124.

$\uparrow$ Article Insecta in Cyclopædia of Practical and Comparative Anatomy, part 17. vol. ii. October 1838. 
nutrition as not so peculiarly characteristic of animal life as necessarily to be adopted as the basis of arrangement; and I rather prefer, with De Blainville and some others, to take, in the arrangement of the Invertebrata, those parts of the body which seem more especially to distinguish the animal from the vegetable creation, and which have obtained the preference in the classification of the Vertebrata, viz. the skeleton and organs of locomotion, together with the nervous system, that peculiar structure by which the animal functions are governed, and the being elevated by its greater instinct or intelligence. The organs of nutrition certainly are more of a vegetative than of a truly animal character, and as compared with those by which the functions of all the organs of the body are excited and controlled and the acts of the being itself are regulated, seem to deserve but secondary consideration in any attempt to assign to that being its proper position in the scale of creation. Every naturalist is aware that we are unable satisfactorily to trace a direct continuity of form or structure from the lowest of one class to the most perfect of that next below it ; because in each class there is a gradual convergence to some rudimentary condition, in which the animal is of very inferior grade, and its principal organs are those of the vegetative character. This, as is well known, is in a marked degree the case even in some of the Vertebrata, as in Fishes, in which there is a gradual transition from the perfect cartilaginous species, the Sturgeons, Sharks and Rays, to the imperfect vermiform Lampreys and Lancelet, of which last naturalists at first doubted whether it belonged even to the Vertebrata, or whether it was not one of the Mollusca or the Vermes. In like manner the Mollusca, which, in consequence of their highly developed organs of nutrition, were placed by Cuvier at the head of the Invertebrata, pass to the Salpoe and Pyrosomee, some of the most imperfectly organized beings. These facts have induced me to pay less consideration to what otherwise might be regarded as objections to the arrangement $I$ am about to propose. On this account $I$ have adopted the skeleton and organs of locomotion, together with the nervous system, as the foundation of an arrangement, and as affording the most distinctive marks of the higher development of animals. I propose to place the subkingdom Articulata at the head of the Invertebrata, and, following in the steps of our distinguished countrymen Kirby and Spence, to commence with the Hexapods, the true Insects, and after these the Octopods, the 
with Observations on the General Arrangement of the Articulata.

Arachnida, and the Decapods, the Crustacea, to be followed by the Myriapoda, the Annelida, and the remainder of the Articulata.

It may be urged against this mode of arrangement that it is not entirely in accordance with some parts of the internal anatomy of these classes, especially in the supposed inferiority of structure of the circulatory and digestive organs in true Hexapods. But I bave elsewhere shown* that this supposed inferiority is not correct, and that a circulation in distinct vessels does really exist in perfect insects, as in the Arachnida and Crustacea, although the vascular structures are less easily detected in insects, on account of their smaller size and greater delicacy, in consequence of the much smaller size of the animals themselves; while a distinct arrangement of circulatory vessels distributed over the internal organs, as well as to the muscular structures, exists also in the Myriapoda. As regards the anatomy of the digestive organs, many insects have these parts more perfect than the Crustacea, or even the higher Mollusca, as, for instance, the Orthoptera. The supposed superiority of structure of the digestive apparatus in the Arachnida and Crustacea is chiefly in the more perfect development of some of the glandular appendages, as the liver, which, as an excretory organ designed to separate from the circulatory fluids a greater quantity of carbonaceous matter + than could be thrown off readily by the branchiæ or pulmono-branchiæ, may be rendered necessary in these classes on account of their peculiar habits. In regard to their nervous system, Insects appear to be much superior to the Crustacea and to the Arachnida, although the contrary has usually been supposed. I do not regard the mere accumulation of nervous matter in any portion of the cord on the thoracic or ventral region of the body as indicatory of a higher development of the animal, because such accumulation is necessarily consequent on the size and number of the organs of locomotion which are collected more or less nearly together in some portion of that region; and because the ventral cord with its ganglia is the analogue only of the medulla spinalis with its enlargements in the Vertebrata. But I am inclined to believe that the supra-cesophageal ganglia, which recent experiments, elsewhere detailed + , have convinced me are alone endowed with the functions of a true brain, and consequently are the true analogues of the 
brain of Vertebrata, are those parts of the nervous system which indicate high development. The relatively greater development of these parts, as compared with that of the other portions of the nervous system in the different classes of the Articulata, seems to indicate that Insects, as a class, are superior to the other classes. In support of this view I need but refer to the great development of the cerebral portion of the nervous system in the gregarious Hymenoptera, so remarkable for their half-reasoning intelligence. In these insects the development of the brain, as compared with that of the other parts of the nervous system and of the body, exceeds that of any of the other Articulata. The perfection of organization, as seen in the most perfect forms of the Vertebrata, is the performance of the voluntary functions of the body by the most concentrated means. A relatively inferior size of the cerebral portion of the nervous system, and an increased number of organs of locomotion, may thence be regarded as proofs of a lower type of development. This view is supported by the small size of the cerebral ganglia and by the existence of abdominal legs for locomotion in the larvæ of Insects. These cerebral ganglia are always increased in size, and the abdominal legs have entirely disappeared when the insect has arrived at its perfect state, in which its voluntary powers are greatly augmented, and its organs of locomotion are concentrated in the thoracic region of the body. It may be urged, in opposition to this view, that an accumulation of nervous matter on the ventral surface of the body exists also in the Arachnida and Crustacea; but there is no correspondent enlargement in these classes of those portions of the nervous system, the supra-œesophageal ganglia, on which the instinct and intelligence of the animal seem entirely to depend, while the increased number of organs of locomotion indicates in them a lower type of formation.

These are the considerations which induce me to place the Articulata at the head of the Invertebrata, and the hexapod Insects above the Arachnida and Crustacea. The many analogies that exist between the Crustacea and the Myriapoda, both in external form and in the structure of some of their internal organs, show the close affinity of these two classes. On the other hand, the manner in which the Myriapoda are developed on their leaving the ovum, and the periodical formation of new segments to the body, show their near approach to the Annelida. 
with Observations on the General Arrangement of the Articulata. 273

The division of the Myriapoda into tribes and genera has been subject to as much difference of opinion as their establishment as a distinct class, and the assignment of their position in the animal kingdom. Lamarck, who arranged them with the Arachnida, divided them at first into three genera, Scolopendra, Scutigera and Iulus, and subsequently added a fourth genus, Pollyxenus. Latreille in his later works removed them from true Insects, among which he had originally placed them, and constituted them into an order of the Arachnida, dividing them into two families, Chilognatha and Syngnatha. Dr. Leach adopted these families as distinct orders. He divided the first into three families, Glomeridee, Iulidre and Polydesmidce; and the second into two, Scolopendridce and Geophilidoe. Subsequently to this Latreille* divided the class into the orders Chilognatha and Chilopoda. These were adopted by Gervais $\dagger$, but were redivided by that naturalist, the former into the Oniscoidece and Iulidece, and the latter into Scutigeridece and Scolopendridece. But before the production of Gervais' arrangement $M$. Brandt had begun to rearrange the class $\neq$, and had proposed to divide the Chilognatha into sections, which were again divided into families and genera. Subsequently to this, on finding that the organs of nutrition in some species were especially adapted for taking liquid food, he proposed to divide the class into the Myriapoda manducantia and Myriapoda sugentia, and he has recently republished his valuable observations on this subject\$. Still more recently M. Lucas \| has published an arrangement of the class, and has followed the views adopted by Gervais, with a slight alteration of the names of the families. The arrangement proposed by Brandt is by far the most natural that has yet appeared, and is of great value so far as regards the division into families and

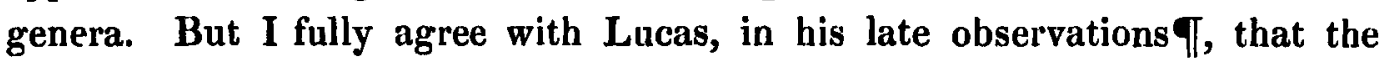
existence of a genus of siphonophorous Myriapods closely allied to Scolopendra necessarily tends greatly to modify the views of Brandt in regard to the division of the class in the manner proposed by him. Added to this, it

* Cours d'Entomologie, 1831.

$\dagger$ Loc. cit.

$\ddagger$ Bulletin de la Soc. Impériale des Nat. de Moscou, tom. vi., 1833, p. 194, \&c.

$\$$ Recueil de Mémoires, \&c.

|| Hist. Nat. des Crustacés, des Arachnides et des Myriapodes, tom. iv., 1840.

ๆ Annales de la Société Entomologique de France, deuxième série, t. i., 1843, p. 50. 
may be remarked, that the structure of the internal parts of the mouth in the Scolopendridoe and Geophilidoe seems equally fitted for taking liquid as well as solid aliment. On this account $I$ bave been unable to adopt his primary division into masticating and sucking Myriapoda in my arrangement of this class, but have followed his plan closely in the formation of the families, sections and genera and in the characters assigned to them. His tribes $I$ have considered, with Latreille, as distinct orders, and his families as tribes. The alterations made in the arrangement of the genera are those which Brandt himself would have followed, had he assigned to this class a position below the Crustacea instead of above them, a situation which the close affinities they bear to the Annelida fully justify me in proposing. The circumstance which led Brandt to place his Pentazonia at the bottorn of the order Chilognatha was their close affinity with the Crustacean family Oniscidae; and it is this very circumstance which now leads me to place them at the top. Those genera which seem to have the closest connexion with the Annelida are the vermiform Iulidae. These not only have an affinity with the Annelida in the situation of their respiratory organs near the median line on the ventral surface of the body, but also in their multitude of segments, and in the number of new segments periodically acquired. Of this family the Spirostrepti seem to occupy the lowest position, on account both of the number and simplicity of their segments. The Pentazonia, which have the smallest number of segments, appear on that account to connect the Chilognatha with the Chilopoda. These are the views adopted in the following synoptic table of arrangement and characters of the genera.

\section{Synopsis Generum.}

Ord. 1. CHILOPODA, Latr.-Caput latum, prominens. Corporis segmenta inæqualia; singula par unicum pedum ad latera segmentorum insertorum gerentia. Mandibulæ prominentes, acutæ, falciformes. Organorum sexualium apertura ad extremitatem analem.

Trib. 1. Schizotarsia, Brandt.-Antennæ pluri-articulatæ, graciles, corpore longiores. Tarsi longi, pluri-articulati, inæquales. Oculi compositi, prominentes, globosi. 
with Observations on the General Arrangement of the Articulata.

Fam. 1. Cermatiida, Leach.-Scuta dorsalia 8 ; singula segmenta 2 ventralia obtegentia. Stigmata mediana.

Gen. 1. Cermatia, Illig.-Oculi prominentes. Caput transversum. Scuta dorsalia emarginata. Stomatum latera incrassata.

Trib. 2. Holotarsia, Brandt.-Tarsi 3-articulati. Caput e segmentis 2 mobilibus efformatum. Antennæ corpore haud longiores, setaceæ vel filiformes, 14-60-articulatæ. Oculi stemmatosi, aggregati, simplices vel nulli.

Fam. 2. Lithobiida, Newp.-Scuta dorsalia 15, subquadrata, inæqualia; angulis elongatis, acutis. Coxarum paria posteriora excavationibus ovatis.

Gen. 2. Lithobius, Leach.-Ocelli numerosi. Caput latum, depressum. Labrum denticulatum.

Gen. 3. Henicops, Newp.-Segmentum cephalicum latum. Dcellorum par unicum.

Fam. 3. Scolopendrida, Leach.-Segmenta podophora 21 vel 23. Pedes posteriores incrassatæ; articulo primo vel secundo spinoso.

Gen. 4. Scolopendra, L.-Segmentum cephalicum cordatum, imbricatum. Ocellorum paria 4. Spiracula valvularia.

Gen. 5. Cormocephalus, Newp.-Segmentum cephalicum posticè truncatum. Spiracula valvularia.

Gen. 6. Rhombocephalus, Newp.-Segmentum cephalicum basilareque rhomboidea. Labium angustatum.

Gen. 7. Heterostoma, Newp.-Segmentum cephalicum truncatum. Dentes magni. Spiracula cribriformia, in paribus 10.

Gen. 8. Scolopendropsis, Brandt._Segmentum cephalicum truncatum. Pedum paria 23.

Gen. 9. Theatops, Newp.-Ocelli distincti. Antennæ 17-articulatæ subulatæ. Pedes posteriores clavati. Labium dentatum.

Gen. 10. Scolopocryptops, Nerop._Segmenta podophora 23. Segmentum cephalicum cordatum, imbricatum. Labium haud denticulatum. Antennæ 17-articulatæ.

voL. $\mathbf{x I X}$. 20 
Gen. 11. Cryptops, Leach.-Segmenta podophora 21. Ocelli nulli vel absconditi. Antennæ 17-articulatæ. Labium haud denticulatum.

Fam. 4. Geophilide, Leach.-Segmenta subæqualia, singula e subsegmentis 2 completis sed inæqualibus efformata. Segmentum anale pedibus brevibus styliformibus.

Subfam. 1. Scolopendrellina, Newp.-Corpus breve, crassum. Antennæ 14-20-articulatæ.

Gen. 12. Scolopendrella, Gervais.-Pedum paria 10. Antennæ moniliformes, 14-20-articulatæ.

Subfam. 2. Geophilina, Newp.-Segmenta numerosa. Antennæ 14articulatæ.

Gen. 13. Mecistocephalus, Nerop.-Segmentum cephalicum angustissimum, elongatum. Corpus attenuatum. Labium latum, integrum.

Gen. 14. Arthronomalus, Newp.-Segmentum cephalicum subquadratum. Antennarum articuli inæquales. Labium angustum, emarginatum.

Gen. 15. Gonibregmatus, Newp.-Segmentum cephalicum cordiforme, acutum. Antennæ filiformes. Corpus lineare.

Gen. 16. Geophilus, Leach.-Caput subtriangulare. Corpus depressum, gradatim incrassatum. Segmenta pedesque numerosi.

Ord. 2. CHILOGNATHA, Latr.-Caput verticale, rotundatum. Mandibulæ crassæ, robustæ, vel cum labio coalitæ et elongatæ. Segmenta numerosa. Corporis segmenta inæqualia. Pedes superficiei ventrali affixi. Organorum sexualium aperturæ in segmenti $4^{\text {ti }}$ et $7^{\text {mi }}$ superficie ventrali.

Trib. 3. Pentazonia, Brandt.-Corpus ovale, in globum contractile, dorso valdè convexo, ventre complanato. Pedes laminis liberis mobilibus affixi.

Fam. 5. Glomerida, Leach.-Corpus læve, in globum contractile. Oculi distincti.

Gen. 17. Glomeris, Latr.-Ocelli 8, in lineâ laterali curvatâ. Segmenta 13. Pedum paria 17. 
with Observations on the General Arrangement of the Articulata.

Gen. 18. Zephronia, Gray.-Ocelli numerosi, aggregati. Antennæ 6-7-articulatæ, clavatæ. Pedum paria 21.

Gen. 19. Sphærotherium, Brandt.-Ocelli aggregati. Antennæ 7-articulatæ, clavatæ. Pedum paria 21.

Trib. 4. Monozonra, Brandt.-Corpus vermiforme, elongatum. Segmenti singuli dimidia pars anterior cylindrica, posterior lateribus dilatata; laminâ duplici coalitâ ventrali pedum paria 2 gerenti.

Fam. 6. Polyxenida, Newp.-Caput arcuatum, prominens. Corpus latum. Pedes attenuati; coxis maximis. Segmentum anale fasciculis longis.

Gen. 20. Polyxenus, Latr.-Corpus breve, squamis parvis penicillatis vestitum. Pedum paria 13.

Fam. 7. Polydesmida, Leach.

Subfam. 1. Oculi nulli vel obscuri.

Gen. 21. Fontaria, Gray.-Corpus convexum. Segmenta imbricata; laminis lateralibus deflexis.

Gen. 22. Polydesmus, Latr.-Corpus depressum, subconvexum; laminis lateralibus horizontalibus.

Gen. 23. Strongylosoma, Brandt,-Corpus cylindricum. Segmenta tumida; laminis lateralibus rotundatis subnullis,

Subfam. 2. Oculi distincti.

Gen. 24. Craspedosoma, Leach.-Ocelli numerosi, aggregati, Corpus depressum; laminis lateralibus prominentibus.

Gen. 25. Platydesmus, Lucas.-Ocelli duo, magni, prominentes. Corpus depressum; laminis lateralibus prominentibus.

Gen. 26. Cambala, Gray.-Ocelli serie simplici curvatâ. Corpus cylindricum; laminis lateralibus brevissimis, in porcam simplicem desinentibus.

Trib. 5. Bizonia, Newp.-Corpus subcylindricum; laminis nullis marginalibus, Antennæ 7-articulatæe, clavatæe. Segmenta numerosa; singula e subsegmentis 2 coalitis efformata, pedumque paria 2 gerentia.

Fam. 8. Iulide, Leach.-Corpus cylindricum; laminis lateralibus nullis, Segmenta e subsegmentis 2 coalitis efformata. 
Subfam. 1. Synpodopetaline, Newp._Pedes laminis immobilibus affixi.

Gen. 27. Iulus, L.-Caput convexum. Corpus cylindricum. Prothoracis latera triangularia. Antennæ elongatæ.

Gen. 28. Unciger, Brandt.-Squama inferior analis mucronata. Corpus cylindricum.

Gen. 29. Spirobolus, Brandt.-Caput convexum. Oculi subtetragoni. Corpus subpyramidale. Prothoracis latera triangularia. Antennæ breves.

Gen. 30. Spiropœus, Brandt.

Gen. 31. Spirocyclistus, Brandt.-Antennæ breves. Oculi elongati, triangulares. Thoracis latera brevia, triangularia.

Gen. 32. Spirostreptus, Brandt.-Antennæ breves, articulis infundibulatis. Oculi transversi. Prothoracis latera elongata vel dilatata.

Subfam. 2. Lysiopetalina, Newp.-Pedes laminis mobilibus affixi.

Gen. 33. Platops, Newp.-Caput parvum, complanatum vel concavum. Pedes graciles, elongati. Corpus pyramidale, elongatum.

Gen. 34. Lysiopetalum, Brandt.-Frons dilatata. Pedes laminis liberis mobilibus affixi.

Fam. 9. Polyzonida, Newp. (Ommatophora, Brandt).-Ocelli conspicui, fronti inter antennas in seriebus transversis inserti.

Gen. 35. Polyzonium, Brandt.-Ocelli 6 parvi, in seriebus 2 transversis. Corpus depressum.

Gen. 36. Siphonotus, Brandt.-Ocelli 2, in serie simplici transversâ.

Fam. 10. Siphonophorida, Newp. (Typhlogena, Brandt).-Oculi nulli.

Gen. 37. Siphonophora, Brandt.-Caput conicum, elongatum. Nutritionis organa rostriformia, elongata. 


\section{Externar ANatomy.}

Before I proceed to describe the species of Myriapoda, it is necessary that some notice should be taken of the general external anatomy of the class, in order that we may be enabled better to understand the analogies and to trace the origin of the structures which enter into the composition of the head, that portion of the animal from which most of the characters of the genera are derived. The laws which govern the development of this region of the body in the Myriapoda regulate not only the whole form of body in all the Articulata, and the changes from that of the elongated, cylindrical, segmented larva, to the compact, highly organized and complicated body of the perfect insect, but they regulate also the form of body and development of every structure in the Vertebrata, even including those of our own system.

It is on the varied extent to which some entire segments, or certain portions of some of the segments, are developed in the embryo or in the larva,-more especially those in the anterior part of the body, - that the peculiar form of every articulated animal depends.

Every segment of an articulated animal is a compound structure. The identity of those parts which enter into the composition of the segments of the thorax of hexapod Insects has already been admirably pointed out by Professor Audouin. The principles on which the changes take place, and the analogies which the appendages of the head bear to those of the other regions of the body, had previously been shown in the excellent researches of Savigny. My object, therefore, is now to develope still further the principles already laid down by these authorities, and to point out the existence of parts in the skeleton of the Myriapoda analogous to those which have been shown in Insects; and also to offer some additional proofs of the universality of the great laws of development by the aggregation and coalescence of contiguous structures, as shown most distinctly in the aberrant class, Myriapoda.

Naturalists are aware that in all the Articulata the organs of support are on the exterior surface of the body, and consist entirely of certain portions of the tegument in which eartly matter is deposited and consolidated. This dermo-skeleton affords an unyielding surface of attachment for the muscles, and more or less completely encases the whole body. In the higher Articu- 
lata the original division of the skeleton into segments is less apparent than in the Myriapoda, in which each segment remains distin th throughout life. First, then,

$$
\text { Of the Structure of the Segments. }
$$

Every segment of the body, in its normal state, is formed of two arched surfaces, a dorsal and a ventral. Each of these surfaces is originally developed in four parts, two of which are situated on each side of the median line. The two middle ones of the four portions on the ventral surface (TAB. XXXIII. figs. 1 and 2) unite very early to form the single middle portion of the ventral plate $(a)$, and together constitute the single median portion or true sternum. The two lateral pieces (b) are united to the sternal at nearly the same period, and constitute the episternal plates, and the whole form one large, broad, sbield-shaped, abdominal plate to each segment, as is well seen in Scolopendrä, in which genus the two arches of each segment are more uniformly developed than in any other. The longitudinal line of union of the two sternal pieces ( $a$ a ) entirely disappears, but that of the episternal $(b)$ with the sternal remains permanent throughout life as a longitudinal sulcus. This is more especially marked at the anterior border of each plate.

The dorsal arc (fig. 4.), composed like the ventral of four pieces, is less early completed. The two median plates are the last to be united. They form the scutum $(d)$ or upper surface of each segment, along the middle of which there is usually an indication of its original longitudinal line of separation. This longitudinal line, or depression, corresponds internally to a longitudinal line of attachment for the median suspensory muscles of the heart, or so-called dorsal vessel, in each segment. The two lateral portions of the dorsal arc are united longitudinally with the middle ones, and form the episcuta (e), the whole together constituting one large dorsal plate or shield. The relative development of the two arcs of each segment is carried to the greatest extent in all the Myriapoda in the dorsal region, the episcutal plates being always more extensively developed than the episternal.

These are the normal structures in each segment. But the order in which the individual parts are completed on the dorsal surface is the reverse of those on the ventral, This difference appears to have some reference to the relative position of the nervous and vascular systems, The nervous cord in the 
Invertebrata is extended along the ventral surface of the body, and it is that portion in each segment which is first completed; while in the Vertebrata it is extended along the dorsal surface, which in like manner first acquires its definite form. The dorsal surface of the Invertebrata is occupied by the vascular system, and, like the abdominal surface, at which the nutrient vessels of the embryo enter, in the Vertebrata, is the last portion of the external surface of the body that is completed, as may be readily seen in the development of the animal in the ovum. Consequently the dorsal portion of the tegument in the Myriapoda, and other Articulata, is less early completed than the ventral, although often developed to a much greater extent.

Before proceeding further, I ought to state that the mode and order of development of the dorsal and ventral surfaces, as now indicated, refer especially to what takes place in the original formation of the segments which constitute the whole animal in the ovum. Before quitting the egg and the condition of an embryo, the body, in most of the Myriapoda, is composed of only nine segments; although before the animal arrives at its adult state, as first indicated by De Geer, it acquires a periodical addition of new segments. In this post-embryonic development each new segment makes its appearance as a whole structure, immediately beneath the reduplicature of the segment that precedes it; and its composition of definite parts does not become evident until it has nearly attained its full size as a finite part of the body.

The dorsal and ventral arches of each segment are united at their sides by a portion of tegument, in which the appendages of the segments are always developed. One portion of this tegument appears to be subsidiary to each arc. The legs, and their basilar plates, are developed in that portion which belongs to the ventral arch; while the branchial tufts in the Annelida, as already shown by my friend Professor Milne Edwards, the spiracles and organs of respiration in the higher Myriapoda, and the spiracles and supernumerary organs of locomotion, the wings, which are always connected with the respiratory structures, in Insects, make their appearance in that portion which belongs to the dorsal.

Of these subsidiary structures, only those which belong to the ventral arch are developed to any extent in the Myriapoda. Those which belong to the 
dorsal surface, and which, as I have elsewhere* pointed out, acquire in Insects some importance as the paraptera, exist in the Myriapoda only as minute osseous points a little anterior to each spiracle. But those which belong to the ventral arch, and which in Insects are so extensively developed, and are so closely connected with the true ventral plates as to constitute important portions of the skeleton, are also well developed in some of the Myriapoda. These are the epimeral plates on each side (figs. 1 and 2, c c). In Scolopendra they consist of one or more ossified plates, which together form a triangular surface at the side of each segment, anterior to the insertion of the coxæ $(f)$ of the legs. They are in reality subsidiary to these organs of locomotion, and afford attachment internally to the retractor muscles of the limbs.

These are the structures which enter into the composition of each segment. They afford a very precise analogy in the Chilopoda with the parts indicated by Audouin as entering into the composition of the segments in true Insects; in which their actual position in regard to each other varies greatly in different species, but their relative position is always the same as in the more rudimentary form of body in the Myriapoda. It is necessary to state, however, that although the structure of the ventral surface in Insects, as described by Audouin, and that of the Myriapoda, as now pointed out by myself, agrees very closely in every particular, yet there is some difference in the identification of the parts of the dorsal surface. This arises from the circumstance that, in Insects, each segment or division of the thorax is believed to be a compound structure, and was regarded as such by Audouin himself, who conceived that each thoracic segment is in reality formed of four segments of one of the lowest types of development of the Articulata. My own investigations are entirely in accordance with this opinion of Audouin, which I am enabled to bear out by an examination of the segments in Myriapoda. In this class of animals the gradual disappearance of some of these subsegments, as I shall now designate them, is fully apparent, as I shall presently endeavour to show. The names applied by Audouin refer to the whole dorsal plate of each compound segment, and not to the three normal pieces of the subsegments, all which in Insects have completely coalesced into one plate to each distinct segment. Consequently the terms proe-scutum, scutum, scutellum and post-

* Article Inszcta in Cyclopædia of Practical and Comparative Anatomy, vol. ii. p. 915, 1838. 
scutellum refer to the dorsal portion of the first, second, third and fourth subsegments in each division of the thorax. Each of these portions of the segments is originally composed, as now shown in the Myriapod, of a scutum and two episcuta corresponding to the sternal and episternal plates.

\section{Of the Appendages of the Segments.}

The analogy that exists in the anatomy of the segments of the Myriapoda, as compared with other Articulata, is found also in the structure of the appendages, - the organs of locomotion. Each primary segment gives origin to a single pair of legs. These are its normal appendages, and seem, as it were, to complete its development, and to constitute it an integral structure in each animal, the multiple of which constitutes a living body.

The primary parts of each limb (fig. 1.) are the coxa $(f)$, the femur $(g)$, the tibia $(h)$, the tarsus $(i, k, l)$ and the claw $(m)$. These exist in all the Myriapoda, but are less perfectly developed than in Insects. The coxa $(f)$ is developed to a greater extent in the Chilognatha than in the Chilopoda. In the latter order it is a short annular joint, closely connected with the tegument, and inserted immediately above the middle of the episternal plate $(b)$ on each side. It is attached in front to a narrow elongated plate, the trochantin $(n)$ of Audouin, which exists in all the Chilopoda, but which is found only in a very few hexapod insects. Immediately anterior to, and connected with this structure, on each side, are the two epimeral plates $(c c)$, which give attachment to some of the retractor muscles of the leg. These, therefore, are the structures which may be correctly regarded as the basilar portions of the limb. The femur ( $g$ ) is the strongest, and is usually the longest portion of the organ, and is attached to the coxa at its proximal, and to the tibia at its distal extremity. As my object at present is only to point out those parts in the Myriapoda which correspond to others well known in Insects, I shall merely state that the tibia $(h)$ is a short, subcylindrical articulation, similar in almost every respect to the femur. The tarsus $(i, k, l)$ is composed of at least three articulations besides the claw $(m)$. Each of these is rounded, and somewhat tapering towards its distal extremity. The basilar one (i) that articulates with the tibia $I$ regard as a true metatarsus, a structure that is very distinctly developed in all hexapod Insects. The third, or distal articu- 
lation, is very short and small, and gives attachment to a minute joint for the claw, and also to two spines. These parts are subject to much variation of form. In the Cermatiidce the metatarsus is developed to its maximum extent, and the proper tarsal joints are exceedingly numerous, although the primary divisions of the limbs remain the same. In the Scolopendridce they are rounded, smooth and uniform; but in some Chilognatha, as in some species of Spirostrepti, the tarsal joints are enlarged at their distal extremity, and the under surface of one or more of them is often developed into a soft cushion or pad, as in many insects.

\section{Of the Development of the Segments.}

I have already stated that the two arches of the segments are developed more uniformly in the Chilopoda than in any other Articulata. Although I regard this order of Myriapoda as higher in general development than the Chilognatha, yet the latter have the dorsal surface of the body developed to a much greater, and the ventral to a much less extent. In the Chilopoda we have seen that the ventral region of the body, in which the principal animal structures are situated, is broad and powerful, and indicatory of the great strength and activity of the individual. In the Chilognatha, on the contrary, the ventral surface is almost completely atrophied or greatly retarded in its development; while the dorsal surface-the region in which the circulatory and secretory organs, that minister chiefly to the vegetative functions of life, are placed,-is developed to its maximum extent.

We are already aware that it is by a gradual approximation and union of two or more segments, that have acquired their full growth, that the body is divided into separate regions in hexapod Insects. In like manner it is on the union of two segments, or the gradual disappearance of one, and its coalescence with another, that the different but more rudimentary forms of body in the Myriapoda entirely depend. In the Chilognatha the normal segments produced at each change of tegument remain perfectly distinct throughout life, and only acquire their full size by that increment which I have elsewhere described* as the first mode of development,--simple growth. But even in the lowest forms of Chilognatha, in which this first mode is chiefly predominant,

* Philosophical Transactions, 1843, part 2. p. 244. 
the second mode also, the coalescence, or anchylosis of two approximated normal segments, takes place almost at the period of their formation. But the original distinctness of the two continues marked throughout the whole life of the animal, so that each moveable segment of the body is formed of two distinct normal subsegments. Each of these subsegments retains its pair of legs, both pairs being equally developed. This is the condition of the body in the lowest or Iuliform Chilognatha.

In the lower forms of the Chilopoda, the Geophilida, there is a progressive change in the mode of development. This takes place in the ovum. The two subsegments of which each moveable division of the body of the perfect animal (fig. 10.) is composed, and which subsegments are at first equally developed, not only become anchylosed together before the embryo bursts from the foetal coverings, but the posterior $(8)$ of the two $(7,8)$ exhibits a marked superiority of size. This difference continues to increase at each change of tegument, after the animal has left the ovum, until each anterior subsegment has scarcely more than one-half the extent of the posterior. This difference is greatest on the ventral surface (fig. 16.), where the sternal plate of the posterior subsegment covers nearly the whole. Coincident with the beginning of this change and union of each pair of subsegments in the ovum, only one pair of legs is developed to each compound segment, and these have their origin in the posterior of the two subsegments. Notwithstanding this difference in the extent of their development, the rudimentary portions of the anterior segment still exist in the form of minute, partially detached plates at the front of the posterior segment, the dorsal arc being represented by a very short transverse portion.

In the higher genera of Chilopoda, as in Scolopendra (figs. 1 to 4.) the number of compound, moveable segments to the body is greatly reduced, and a further union of the original subsegments has taken place. The upper surface of each moveable segment in this genus is covered by a single plate $(d, e)$, on the anterior part of which there is only a slight indication of the original existence of the first subsegment, in the form of an elevated, narrow, transverse band. But there are still some remains of this subsegment on the ventral surface (figs. 1 and 2.). At the anterior margin of the large ventral plate of each segment, there are on each side of the median line three very short, minute, closely approximated, horny plates, disposed transversely across the under 2 P 2 
surface of each segment $(a, b, c)$. These together form an elongated, triangular surface on each side, the apex of which is directed to the median line. The two pieces that form the apices of these plates, and lie nearest the median line, are the two ununited sternal pieces, which represent the middle portion of the segment that has almost disappeared,-the true sternum $(\alpha)$. Those which are external to these, on each side, in like manner represent the episternal pieces $(b)$, and those on the outside, which form the base of the triangular plates, are the epimeral $(c)$. In these parts we distinctly recognize the atrophied first subsegment. But although the epimeral plates exist, not even the rudiments of lateral appendages are developed, because, as I have distinctly found, in every instance it is necessary that a primary structure should be moulded in its general proportions before it gives origin to its appendages. It is in this way, by changes that take place in the relative development of the rudimentary segments of the embryo in the ovum, that each animal is originally formed on a comparatively higher or lower type, according to the greater or less extent of change which the embryo undergoes in its earliest stages. The form impressed on the future animal, when these changes in the ovum begin to be arrested, usually is that by which its further development is to be regulated; and which it may retain either as a permanent condition, or only as a form that requires to be further matured in postembryonic life before it is fitted to take that which it is ultimately to assume. It is in this way that the coalescing segments of Geophilus become further united in Scolopendra, and are completely lost in single structures in Lithobius and Cermatia, in each instance the union of the rudimentary segments taking place in the ovum, and the type of formation then impressed on the animal being afterwards uniformly repeated at each change of tegument and production of new segments.

The mode in which development takes place, by a union of similar parts, is always centripetal. When any portion of the body has acquired its fullest extent by the first mode, that of simple growth or enlargement, it acquires a tendency to coalesce or become united with similar adjoining structures, either by simple anchylosis of the two, or by a greater or less extent of direct union or coalescence, and the two parts which thus become joined tend to one common centre. 
What takes place in regard to individual structures takes place also in the whole body, as is shown in the transformations of Insects. While some segments of the body of an insect become more or less completely approximated in sections, and divide the body into regions, the whole exhibit the same tendency to approach each other, the head is applied more closely to the thorax, and the thorax is approached by the abdomen.

These, then, are the principles on which the body of an articulated animal is developed, and acquires its proper form and dimensions, and which are carried to their greatest extent in hexapod Insects. They seem to prepare the way for a higher type of development at a much earlier period of the ovum, of the Vertebrata, and to lead to the permanent division of the body, in the more perfect animals, into important regions,--the head, thorax and abdomen.

This view of the principles of development of the body, and of the segments individually, will enable us better to understand the manner in which the most important region of the whole animal, - the head, is constructed, to the examination of which I shall now proceed.

\section{Structure and Development of the Head.}

The Chilopoda, which have the head less completely formed than the Chilognatha, apparently in consequence of their carnivorous habits, afford the best means of tracing the construction of this part, and of observing the changes and gradual approximation of the segments which enter into its composition. The number of segments that form the head of an articulated animal has long been a matter of inquiry. Many attempts have been made to ascertain the fact by examining the head in hexapod Insects, but in consequence of its higher type of development and more compact form in that class, the results arrived at by numerous inquirer's are by no means uniform. The different conclusions have, perhaps, arisen as much from the number of segments that enter into its composition, as from the different species that have been examined, in some of which every trace of some of the segments has disappeared; while some portions are developed to excess in one genus, but are almost entirely atrophied in another. On this inequality depends the form of the organ. Thus Burmeister recognises but two segments; Carus and 
Audouin three; MacLeay and Newman four ; myself, on a former occasion, five; and Strauss Duckheim even so many as seven. After an attentive examination of the head in Myriapoda, I am now constrained to believe that there are not fewer than eight.

I shall attempt to demonstrate the existence of these parts by taking for my guide the appendages of the head and organs of nutrition.

The head of the Chilopoda is formed of two moveable portions (fig. 4.),- the cephalic (A) and the basilar (B, C) segments, as is well seen in Scolopendra. Each of these segments is originally composed of four subsegments. In the inferior genera of Chilopoda, the Geophilida, I have been able to trace most distinctly the number of segments that enter into the structure of the head of this class.

At the moment of bursting the egg-shell*, and before the rupture of the proper fotal coverings, the young Geophilus longicornis (fig. 3.) of Leach has the cephalic segment $(\Lambda)$ formed of four very distinct parts $(1,2,3,4)$, which at that period are in the act of uniting to form the single cephalic segment of the perfect animal (fig. 15.). The anterior of these parts (1) gives origin to the antennce, while the second (2), which has no distinct appendages, is afterwards found to be that in which the minute eyes of the Geophilus are situated. The third (3) and fourth (4) have for appendages the maxillæ and internal parts of the mouth. The whole of these four segments become completely united at this period, more especially the two posterior ones, which afterwards are more enlarged than the anterior, within which the brain of the animal is situated. The anterior always continue very minute, and do not increase in size in proportion to that of any other part of the body.

The parts which constitute the basilar segment of Scolopendra are never all united in the true Geophili. In one of the higher forms of this family, Mecistocephalus, Newp. (figs. 17,18 and 19.), the basilar segment closely resembles that of Scolopendra; but in the other genera (figs. 10 and 15.) it consists of two separate portions $(\mathbf{B}, \mathbf{C})$, the posterior of which (c) I have distinguished in this family as the sub-basilar segment. The original composition of the basilar

* For the purpose of better demonstrating the analogies of the appendages of the cephalic segments, as well as the existence of the segments, I have delineated the head of a young Geophilus at an advanced period after the bursting of the egg. 
segment of four parts is more clearly indicated than that of the cephalic. We have already seen that every normal segment of the body is an integral structure; that it has its separate ganglion of nervous matter; and that it developes one pair of appendages. When one segment becomes atrophied by the enlargement of another, or disappears by uniting with it, the appendages of the atrophied segment either are not developed at all, or are arrested in their further development. If this arrest takes place in the whole structure, the result is merely a liminished size of the organ; but if it be partial, as regards a portion of the structure, the result invariably is an alteration of form. On the other hand, the appendages of the segment that becomes enlarged are always fully developed, and perhaps also are hypertrophied. Now this is exactly what takes place in the development of the segments that form the basilar portion of the head in Geophilus (fig. 3.) and Scolopendra. At the moment of bursting the shell the whole of the segments that form the basilar region of the head are all equally developed $(5,6,7,8)$, and each one has the rudiments of its appendages, a pair of minute tubercles, at its sides. This also is the case with the other segments of the body, the tubercles of which are afterwards developed into legs. During the very few minutes that elapse while the shell and membranes are being fissured, a change takes place in the basilar segments and tubercles. The first and second segments $(5,6)$ become less distinct from each other, and, like the cephalic segments, unite; and the tubercles of the second are considerably enlarged. These are the structures which afterwards become the immense forcipated foot-jaws $(f, g, h, i)$, the true mandibles of the perfect animal, and which are the analogues of the strong mandibles of Insects. The tubercles of the first segment (5) also are further developed, and form the elongated palpi. But the third of these segments $(7)$ is more and more encroached on by the second (6), and its tubercles, which at first are arrested in their development, gradually disappear. The second segment (6) and its appendages continue to enlarge; in consequence of which the first segment (5) also becomes partially atrophied, and the further development of its appendages is arrested. The third and fourth segments unite, like the first and second; the third (7) becoming almost entirely obliterated by the encroachment backwards of the second, and its union posteriorly with the fourth. This latter segment is that which remains 
distinct in Geophilus, the sub-basilar segment (c), that gives origin to a diminutive pair of appendages, - the first pair of legs (figs. 16 and 19.). In Scolopendra the whole of these parts form one structure (fig. 4. B, c). The second of the original basilar segments has not only encroached on the first, which is reduced to a narrow lunated fold on the upper surface, but the third segment has entirely disappeared, and the fourth, or sub-basilar of Geophilus, is also united with it on its upper surface, but retains its original distinction, with its diminutive first pair of legs on the under surface (fig. 5.).

These are the parts that constitute the head and organs of nutrition in Myriapoda, analogous to those which form the head of true Insects.

It has been objected by some naturalists that the foot-jaws of Myriapoda do not properly constitute part of the organs of nutrition; but on tracing the development of the parts, as just described, their perfect identity with the mandibles of Insects is clearly indicated. The basilar region, which in Geophilus and Scolopendra is of great extent, is very much reduced, and the cephalic enlarged, in Lithobius (fig. 29.); and this change is carried still further in Cermatia (fig. 36.). In Lithobius the distinction between the anterior and the two posterior subsegments is marked by a deeply-impressed, lunated sulcus, and the posterior part of the cephalic region of the head is greatly enlarged $(\Lambda)$, while the basilar region is reduced to a narrow transverse ring $(B, C)$, and the minute first pair of legs attached to this region in Scolopendra have entirely disappeared. This change is carried still further in Cermatia, in which the cephalic region $(\Lambda)$ of the head is enormously developed, as also are the organs of sense, and the whole approaches nearer to that of Insects. The basilar region also has united with the cephalic, leaving only its narrow ventral plates, as we shall hereafter find in Iulus, while the mandibles also $(g, h, i, m)$ are enormously developed.

Thus, then, by tracing the changes of the Myriapod from the ovum, and comparing the adult forms of different genera, we are enabled to ascertain the number of the rings that enter into the composition of the head, and also to confirm the original views of Savigny, that the parts of the mouth are the analogues of the organs of locomotion, and acquire their various forms in consequence of the different extent to which their individual parts are developed. 


\section{Comparative Anatomy of the Head.}

We will now compare the anatomy of the head in the different families of Chilopoda, in demonstration of the views $I$ have advanced, respecting the number and order of the segments which enter into its composition in all the higher Articulata.

First, then, of the Geophilidie. The four subsegments observed in the embryo of Geophilus, at the bursting of the shell, and then in the act of uniting to form the future cephalic segment, are faintly indicated in the perfect animal (fig. 15.). 'They are numbered on the accompanying drawings, in their proper order, from one to four. The first or antennal subsegment has almost disappeared in this genus, and its boundary is indicated only by a very faint transverse line; but its appendages, the antennæ, are developed to a greater extent than those of any other segment of the body, and their divisions are multiplied in the exact ratio of the number of parts which usually enter into the composition of the appendages of other segments in Geophilus. This number is exactly doubled in the antennæ, so that the formative principle developed in the first segment of the head is expended on the appendages, which become hypertrophied; while the segment from which they originate, is, in a corresponding ratio, arrested in its development. This change commences at an early period of the embryo, since at the bursting of the shell, when the appendages of all the other segments exist but as very minute tubercles, the antennæ are of great size, and are equal in length to the whole of the four cephalic segments.

The second subsegment does not give origin to moveable appendages, but is the seat of the important function,-vision. This segment is always more developed in Geophilus than the first, and is almost entirely occupied by the great centre of the animal functions and instincts,--the brain.

The third subsegment is developed to a greater extent than the second, and gives origin to appendages which are the first moveable parts of the organs of nutrition,- - the internal maxillex.

The fourth subsegment is enlarged to a much greater extent than either of the others, and is equal in length to the whole of the three anterior segments. This greater size appears to have some referente to the development and voL. XIX. 
importance of its appendages, which are large, three-jointed and palpiform, and seem to represent the external or maxillary palpi of Insects. They are situated one on each side of what has heretofore been described as the internal labium, but which, I conceive, may be regarded as the lingua. This structure, which is well seen in Scolopendra (fig. 7.), is formed of two elongated, delicate plates $(c, c)$, situated between the palpi, and forming the floor of the entrance to the pharynx, which they close in below. They seem to be the proper episternal portions of this segment of the head.

Although these subsegments are all clearly indicated in the perfect state of Arthronomalus (Geophilus) longicornis, Leach, some of them only are distinguishable in other species, as in the true Geophili (fig. 10.) and Gonibregmati (fig. 4.), in which the head has assumed a more compact form, and the antennal subsegment is alone distinguished; while all trace of the divisions is entirely obliterated in the narrowed and elongated cephalic segment of Mecistocephalus (fig. 18.). In Cryptops (fig. 20.) and Scolopendra (fig. 4.) there is an indication of the extent of the antennal subsegment, but, as in Geophilus, an entire obliteration of the others. This also is the case in Lithobius (fig. 27 and 29.), in which the boundary of the antennal segment is marked by a deep curved suture. In Cermatia (fig. 36.) the whole cephalic region has assumed a new form; the antennal and optic segments being now extensively developed, and occupying the larger portion of the head, and the organs of vision have encroached backwards on the third subsegment.

The four subsegments that form the posterior part of the head are more slowly united in the basilar region. In Geophilus this union is only commenced. The $f$ ffth and sixth segments of the young animal, each, as we shall presently see, developing a pair of large appendages, unite at a much later period than the cephalic subsegments. The fifth unites with the sixtb, but not until the primary divisions of its appendages are modelled, and not without leaving a portion of its dorsal surface attached to the sixth, indicating its original separation. This is most distinctly shown in Mecistocephalus (fig. 17 and 18.), in which it remains as a small quadrangular plate (5.). It exists also in Scolopendra in the form of a raised lunated fold, on the anterior margin of the great basilar segment (fig. 4, B). But in the higher genera this also has disappeared. 
The seventh and eighth segments, which together form the sub-basilar segment (fig. 15, c) in Arthronomalus, unite at a very early period, even before any appendages are developed. But a trace of the seventh subsegment exists in all the true Geophili (fig. 10.), and even in Arthronomalus longicornis. Although the sub-basilar segment itself remains distinct, and supports the first pair of legs in the true Geophili, it becomes united to the basilar in the higher genus of this family, Mecistocephalus (fig. 17.), and forms with it one large segment $(6,7,8$.$) , that bears a pair of atrophied legs posterior to the proper organs of$ nutrition. These atrophied legs indicate the original distinctness of the subsegments in all the Geophilide and Scolopendride; but these also are lost in the Lithobiidce, in which the whole basilar region of the head is reduced on the dorsal surface to a narrow ring (figs. 27 and $29, \mathrm{~B}, \mathrm{c}$ ), and the cephalic region (A) is enormously developed.

To trace the manner in which these changes in the structure of the head are effected, we must return again to the young Geophilus. We have seen that shortly after the animal has left the ovum, the cephalic segments are nearly all of the same size, but that the fourth is soon enlarged, so as to equal in extent the whole of the others; while the first is more and more retarded in its development. The enlargement of the cephalic region of the head in Chilopoda thus takes place in a backward, as we shall presently find the basilar region does in a forward direction; the two regions thus tending to one common centre. This fact is proved by a comparison of the head in the different families of Chilopoda. In Cryptops (fig. 20.) the cephalic region has acquired a large extent, as compared with the Geophili, and this increased size is maintained in most of the Scolopendridae (fig. 4.), until, in Lithobius (fig. 29.), we find the cephalic region constituting nearly the whole head. It has been developed backwards, not only so as to cover the greater portion of the united basilar and sub-basilar segments, but also to occasion them to become atrophied to a simple short segment (B, c). In Cermatia (fig. 36, $\mathrm{A}$ ) this change has been carried to its maximum extent. The cephalic region now forms the whole upper surface of the head, and entirely covers the basilar region, which, in consequence, is so completely atrophied as to leave but a trace of its existence on the upper surface, covered by the cephalic portion; while the formative powers have been expended in the development forwards of the remaining 
ventral portion of this region, and in its enormous appendages $(f$ to $m)$, - the articulated foot-jaws, - the analogues of the mandibles of Insects.

This mode of tracing the formation of the head in the Chilopoda may enable us to understand the principles on which the more complicated organ in the higher Articulata, the hexapod Insects, is developed in the ovum : first, by an aggregation of the normal constituents of the part into distinct regions; and then by the anchylosis, or the coalescence of these into one structure; by the extension backwards of the cephalic, and forwards of the basilar portions ; the different configuration of the whole being dependent on the greater or less extent to which individual parts are enlarged.

\section{Organs of Nutrition.}

To trace the analogies of these parts we must compare them with the simple appendages of the segments-the legs, all the divisions of which exist, almost in theic relative proportions, in the mandible of the young Geophilus (fig. 3.) at that stage of growth which $I$ have elsewbere described * as the fourth period in Iulus. The mandible, at the bursting of the egg, is only a simple tubercle to the sixth segment of the head, precisely similar in every respect, of form and size, to the tubercles of other segments of the body, which afterwards become organs of locomotion, \&c. But during the short space of time that elapses while the embryo is escaping from the egg, and before it has rid itself of the fotal membrane, this little tubercle is enlarged to twice the size of the others, and continues to increase, and undergoes a change in the relative development of its parts, which so modifies its whole form as to adapt it for the runction of prehension and manducation, instead of locomotion. The tubercles of the other segments have all their parts developed equally; but those which are to become the mandibles, and be fitted for a different function, are not only more rapidly enlarged, but have the coxa and femur more advanced than the other articulations. In the appendages, then, as we have already seen in the segments, the configuration of the whole organ, and the special adaptation of its structure to a peculiar function, consist in the greater or less development of its original parts, and not in the introduction of a new element into its composition. The coxal articulation of the mandible $(f)$ always exists

\footnotetext{
* Phil. Trans, 1841, part ii. p. 121.
} 
throughout life, and it is by means of this that we are enabled to determine with precision the identity of the different parts of the organ. Even so early as the fifth period of growth it becomes in part consolidated with the episternal plates of its segment, in the formation of the broad under surface of the head. The femur $(g)$ continues to enlarge, and forms the chief portion of the mandible; while the tibial $(h)$, metatarsal $(i)$ and tarsal joints $(k)$ are all more and more arrested in development, and at length remain but simple rings, that support and bend the prehensile extremity of the organ,- the enormously developed claw $(n)$. An additional proof of the identity of the chief portion of the mandible with the femur of the legs is afforded in its armature. The internal angle of the distal extremity of this part in the Scolopendridce is usually developed into a long process or spine (fig. 22, s), which is sometimes furnished with one or more tubercles. I have designated this process in the mandible the mandibular tooth, and have employed it in the description of species. 'The femul' of the posterior legs is also developed into a long process, precisely similar to that of the mandibles. The identity of these parts is even more strongly marked in Cermatia, in which the under surface of the femur of all the legs is armed with a strong spine, while a similar spine exists at precisely the same place on the corresponding portion of the mandibles. In Scolopendra, Lithobius and Cermatia one of the tarsal articulations has disappeared, and the otbers with the tibia are reduced to their minimum. In Mecistocephalus, Cryptops and Geophilus the coxa becomes in part united with the episternal plates by simple anchylosis, but remains entire in Scolopendra and Lithobius. 'The sternal and episternal plates are largely developed and consolidated together, to form the broad inferior labium, at a very early period in the young Geophilus, and are enlarged to their fullest extent in Mecistocephalus. The original distinction of these parts is clearly indicated in Cryptops anomolans (fig. 26.), and more decidedly in some Scolopendrce. In Lithobius and Cermatia the sternal plates are almost entirely atrophied, but the episternal and epimeral are expanded to form the whole of the broad labium. They are perfectly distinct from, but articulated with the narrow sternal portion of the segment. In the very young Lithobius (fig. 30.) the episternal plates of the basilar segment are two curved, elongated laminæ $(b)$, perfectly distinct, and widely separated from each other in their middle portion, with a broad interspace between 
them ; but approximated together at their inner anterior margin, which, united with the epimeral plates $(c)$, forms the denticulated front of the labium. The space between the plates is gradually filled up in the young animal, partly by a widening of the plates themselves, and partly by the consolidation with them in the middle line of the remnant of the atrophied sternal plate of the preceding segment, that has given origin to the posterior pair of palpi (fig. 6.). The deep sulcus in the middle of the labium of the perfect animal is the indication of these unions. In Cermatia the close approximation of the episternal plates in the middle line does not take place, but the two remain distinct throughout life; while the epimeral plates, that form the border of the lip, have their denticulations elongated into spines. These epimeral plates are well developed in Scolopendra (fig. 5*), and are indicated by sutures, although they are absent in Geophilus ; are developed without marginal teeth in Cryptops; and are small, and consolidated with the episternal plates in Lithobius (fig. 31, d) and Cermatia. In Scolopendra they are often formed each of two pieces, analogous to those on the segments. I have distinguished these as the dental and subdental plates $(d, e)$. The latter are very minute and without denticulations, but are marked by sutures, which distinguish them from the episternal pieces, as other transverse sutures divide the latter from the sternal (fig. 5.).

The chief parts which we have traced in the mandibles and inferior surface of the basilar segment, exist also in the other organs of nutrition and their segments. Thus, in the part which has been described by Savigny and others as the first auxiliary lip (fig. $6, b, f$ ), which is situated anterior to the structures we have just examined, and is the sternal portion of the fifth segment of the head,-the true sternum is atrophied, and united in the middle line with the episternal plates of the succeeding segment, the great basilar region, as we have seen in Lithobius. But the episternal plates remain as broad irregular laminæ (fig. 6, $b$ ), articulating on their front with two transversely elongated plates, the analogues of the coxæ $(f)$, which form the margin of this auxiliary lip. Both these plates articulate conjointly at their sides with the third joint of the palpus, which may be regarded as the analogue of the labial palpus of Insects. This third joint represents the femur, and the two remaining joints the tibia and tarsus, with the minute claw. Precisely the same structure exists 
in Lithobius as in Scolopendra, excepting only that the femoral portion of the palpus is more elongated. In Cermatia also the same analogies are preserved: the coxa exists on the front of the episternum, but receives the whole articulation of the femur. This joint, like the chief portion of the mandibles, is armed with its spines, as also is the tibia. A considerable elongation has also taken place in these parts, and the tarsus is formed of two joints.

These are the analogies of the most developed and important parts of the basilar region of the head, and the like exist in those of the cephalic region; but it is only by remembering, and by taking for our guide the important fact that the coxal joint of the limb constantly exists, and is never entirely lost, although often in part united with the episternum, with which it always articulates, that we are enabled with certainty to trace these analogies.

The cephalic region of the head, like the basilar, gives origin to two pairs of moveable organs of nutrition. These are the appendages of the third and fourth segments. The posterior pair (fig. 7 .) are connected transversely at their base with a pair of soft appendages $(c, c)$, that are situated between them, and which, as I bave already stated, I regard as the proper lingua, as they form the floor of the entrance to the pharynx. These appendages are the remains of the episternal plates, while the coxæ are represented by the large basal joint of the palpus $(f)$, the external maxillary palpus of Insects. The remaining pair of appendages are the most anterior and internal of the moveable organs of the mouth, and are the true maxillæ (fig. 8.*). They are the appendages of the third cephalic segment. They are formed each of three corneous triangular plates $(g, h, i)$ that articulate freely with each other, and represent the femur, the tibia and the tarsus. They perform the office of comminuting the food before it is passed on to the pharynx.

Besides these moveable parts there are others that are articulated together, and are united at their extremities in the middle line, and form an arch in front of the entrance to the mouth anterior to the moveable organs. These seem to constitute the anterior lip (fig. 8.), and belong to the second segment. They are composed each of two subquadrate horny plates $(h, h)$, articulated together, and united in the middle line by a sharp triangular tooth $(i)$. Although it is difficult to trace with certainty the analogies of these parts, they seem to represent the appendages of the second segment; and there is a very precise 
agreement in their structure and mode of union to form the lip in Scolopendra, Lithobius and Cermatia.

This is the comparative anatomy of the head in Chilopoda; and I trust that I shall bereafter be able to demonstrate a precise agreement in the parts, and their mode of union, in the Chilognatha and in the highest of the Articulata, the hexapod Insects.

Although it is not my intention at present to trace the union of the segments of the body through the genera of Chilopoda to the more perfect Hexapods, I may simply remark that this union is based on precisely the same laws in the body as in the cephalic region,- -union in pairs.

Generic and Specific Characters.

The parts of the skeleton that afford generic or specific descriptions are the antennæ, the ocelli, the dental plates and teeth in the head, the number and form of the segments and legs, the number, form and arrangement of the spines on the femora of the posterior pair of legs, and the form of the anal plates. But so similar are these parts in the different groups, that although they distinctly indicate the different genera, it is only by minute peculiarities of their structure that they assist us in identifying the species. The number and form of the dorsal plates at once characterise the Cermatiidce and Lithobiidae. The number of legs and ocelli mark the Scolopendrida. The definite number of joints to the antennæ and the form of the labium indicate the genus Cryptops; and the multiplicity of segments to the body and the definite number of joints to the antennæ the whole of the Geophilidoe. The parts that serve for subdivisions and also for specific descriptions in the extensive genus $\mathbf{S}$ colopendra are the denticulations of the labium, the number and character of the spiracles, and of the spines on the posterior pair of legs.

The dental plates have not heretofore been employed by naturalists in identifying the species of Myriapoda; but they nevertheless afford good, and the most permanent characters, especially when taken in conjunction with other parts. The denticles on their anterior margin I have called for convenience, labial teeth. They vary in number and size, and are most distinctly marked, as in Lithobius and Scolopendra, and are sometimes, as in some of the latter genus, themselves armed with other denticuli. In Lithobius and 
Scolopendra the full number of teeth is acquired at an early period, usually after the third or fourth change of tegument, when the individual is very small, and before it has gained its full complement of legs. Herice the number and form of the teeth are good characters of species in all that have assumed the adult form. These are, perbaps, the best structural characters in the adult Lithobius when taken in connexion with the number of ocelli. In Cermatia they are uniform in their appearance, and consequently afford only generic characters; but in the great genus Scolopendra the dental plates and the teeth are so developed as to afford both characters for the division of the genus into groups and for the identification of species. Thus in the first division, which seems to be nearest allied to Lithobius, the Parvidentatce, the plates are very short, transverse, and almost quadrangular, and the teeth are very small and more numerous than in the other divisions of the genus. In the second division, the Latidentatce, the plates assume a more peculiar character : they are large, distinctly divided from the lip by a deep suture, and often have the posterior external angle elongated. The teeth on their anterior margin are usually very large and fewer in number than in the preceding division, and are more adapted for cutting and tearing. The internal one on each plate is usually broad and spatulate, and the external triangular and acute. In Rhombocephalus the plates are very much narrowed at their anterior border and widened at their posterior, and are less distinct from the labium than in the other section, and the teeth are fewer or smaller. In Heterostoma the teeth are elongated, and are triangular, larger, and more acute than in either of the others. In Cryptops the plates exist, but the teeth are absent; while in Geophilus the plates also are undeveloped.

The spines on the posterior legs, and the form of the anal plates, as pointed out by Brandt, afford the next best characters for the species and subdivisions of Scolopendra. The spines are not developed on any part of the leg in Scolopendra but the femur, and perhaps also the coxa. The posterior internal angle of the femur is always more or less elongated into a spine, even when spines on other parts of the joint are entirely absent. But the characters derived from this part of the body can only be depended on when the organ is one of the original members, and is not a reproduced limb, since if it happen to be the latter,-which may be known by comparison with the limb of the opposite voL. XIX. 
side, when it will always be found to be a little smaller,- - the spines of the reproduced limb are imperfectly developed, are often entirely wanting, and are seldom or ever arranged in their normal regularity. 'The character derived from the spines must, therefore, be taken in conjunction with others derived from parts that are rarely or ever reproduced; as, for instance, the dental plates, and also the form of the præ-anal plate, and the lateral appendages, or epimeral plates of the posterior pair of legs. These latter parts occasionally offer good characters; they are usually consolidated with the coxæ, the spines being developed from the epimeral plates.

The dorsal plates of the segments sometimes afford generic characters. The existence of the stomata, and the emargination of the posterior border peculiarly characterize the Cermatiido, as the alternation of long and short segments with the angles of the latter elongated and pointed do the Lithobiida.

The ocelli afford secondary characters of species in Lithobius; since, although their number varies at different periods of growth in the same individual, as first pointed out by Gervais, and confirmed by my own observations, it generally differs in the adult state of different species. When the young Lithobius comes from the egg, it has but a single ocellus on each side of the head, but this is increased to three on each side at its next change. This number is further increased at the subsequent changes, but not until after the animal has acquired its full complement of legs, and then the number is increased in a certain ratio at each change of skin. But it does not obtain its full complement until it has very nearly approached its adult size, so that the organs of vision, as in the true Hexapods, are among the last of the external organs that are completed. Even in the adult state the number varies slightly, so that this character cannot be depended on alone, but must be taken in connexion with the number of labial teeth. In the other genera of Chilopoda the number of ocelli is fixed in each genus.

The number of joints to the antennæ is a distinct generic character in Cryptops and Geophilus. It has sometimes been employed, as by Gervais, to assist in indicating the species of Scolopendra, but it is very little to be depended on. In Cryptops and Geophilus the full number is acquired at a very early period; in the latter even soon after leaving the ovum. But this is not the case in Lithobius; and probably also not in Scolopendra. In Litho- 
bius there are usually more than thirty-eight, and in one species even so many as sixty joints in the antenna. In Scolopendra there are seldom more than twenty, or fewer than seventeen. But although I have little doubt that the number is in reality fixed in each species of the latter genus, it cannot be taken as a good character, as it is often found to vary not only in the antennæ of different individuals of the same species, but even in the two antennæ of the same individual. It can only be received as a secondary character, and when the number corresponds in both antennæ.

\section{DESCRIPTION OF TAB. XXXIII.}

Figs. 1 and 2. The ventral surface of one segment of the body of Scolopendra Hopei, Newp. $a$. The two united sternal plates. $b$. The episternal. $c, c$. The epimeral. $f$. The coxa. $g$. The femur. $h$. The tibia. $i$. The metatarsus. $k, l$. The tarsus. $m$. The claw.

Fig. 3. The lateral view of the head of a very young Geophilus, Arthronomalus (Geophilus) longicornis, Leach. A. The cephalic segment formed of its four subsegments 1 to 4 . B. The basilar segment. c. The sub-basilar segment. $f$ to $m$. The great mandible in the progress of development.

Fig. 4. Head of Scolopendra Hopei, Newp. A. Cephalic segment. B, c. The united basilar and sub-basilar segments. $d$. The scutum. $e$. The episcuta on each side. $g$. The femoral joint of the great mandibles or foot-jaws.

Fig. 5. The under surface of the head of the same species. $5 * d$. The dental plates. $e$. The subdental plates.

Fig. 6. The labrum and palpi : the letters as in fig. 1.

Fig. 7. The maxillary palpi. c, c. The lingua.

Fig. 8. The labrum or anterior lip. $c, c$. The lingua: the other letters analogous to parts in fig. 1. $8 *$. The maxilla.

Fig. 9. The inferior surface of the cephalic region of the head, showing the labrum and maxilla in situ.

Fig. 10. Head of Geophilus subterraneus. A. The cephalic segment. B. The basilar segment. c. The sub-basilar segment.

Fig. 11. Head of Gonibregmatus Cumingii, Newp.

Fig. 12. Under surface of the same. 
Fig. 13. Superior surface of the extremity of the body in the same.

Fig. 14. Inferior surface.

Fig. 15. Superior surface of head of Arthronomalus longicornis, Newp. A. Cephalic segment. B. Basilar ditto. c. Sub-basilar ditto.

Fig. 16. Inferior surface of the same. $g, m$. The mandible.

Fig. 17. Head of Mecistocephalus punctifrons. Newp.

Fig. 18. Head of Mecistocephalus punctilabratus, Newp.

Fig. 19. Inferior surface.

Fig. 20. Head of Cryptops sexspinosus, Say.

Fig. 21. Superior surface of termination of body in the same.

Fig. 22. Inferior surface. $q$. The preanal scale. $r$. The lateral anal appendages, or united coxa and epimeral plates. $s$. The femoral spines.

Fig. 23. Labium of Cryptops.

Fig. 24. Inferior surface of head of ditto.

Fig. 25. Head of Cryptops anomalans.

Fig. 26. Inferior surface of head of the same.

Fig. 27. Head of Henicops.

Fig. 28. Under surface of the head of the same. b, c. Labrum. f, g. Mandibles. A. Cephalic; $\mathbf{B , ~ c . ~ B a s i l a r ~ s e g m e n t . ~}$

Fig. 29. Lateral view of the head of Lithobius americanus, Newp.

Fig. 30. Under surface of the head of a very young individual of Lithobius Leachii, showing the two halves of the labium not yet united.

Fig. 31. Labium of Lithobius.

Fig. 32. Labium of Lithobius.

Fig. 33. Dorsal surface of the body in the family Lithobiida.

Fig. 34. Ventral surface of the terminal segments and legs in Lithobius. a. The transverse excavations in the coxæ.

Fig. 35. Lateral view of the head in Scolopendra Hopei. 1, 2, 3, 4. The cephalic region. $5,6,7,8$. The united basilar and sub-basilar regions. $a, b$. The first and second spiracles.

Fig. 36. Head of Cermatia. A. Cephalic region. B, c. The atrophied basilar region. $f$ to $m$. The mandible.

Fig. 37. The dorsal plates in Cermatia. o, o. The stomata. p. The marginal spines.

Fig. 38. The terminal portion of body in the same genus. 

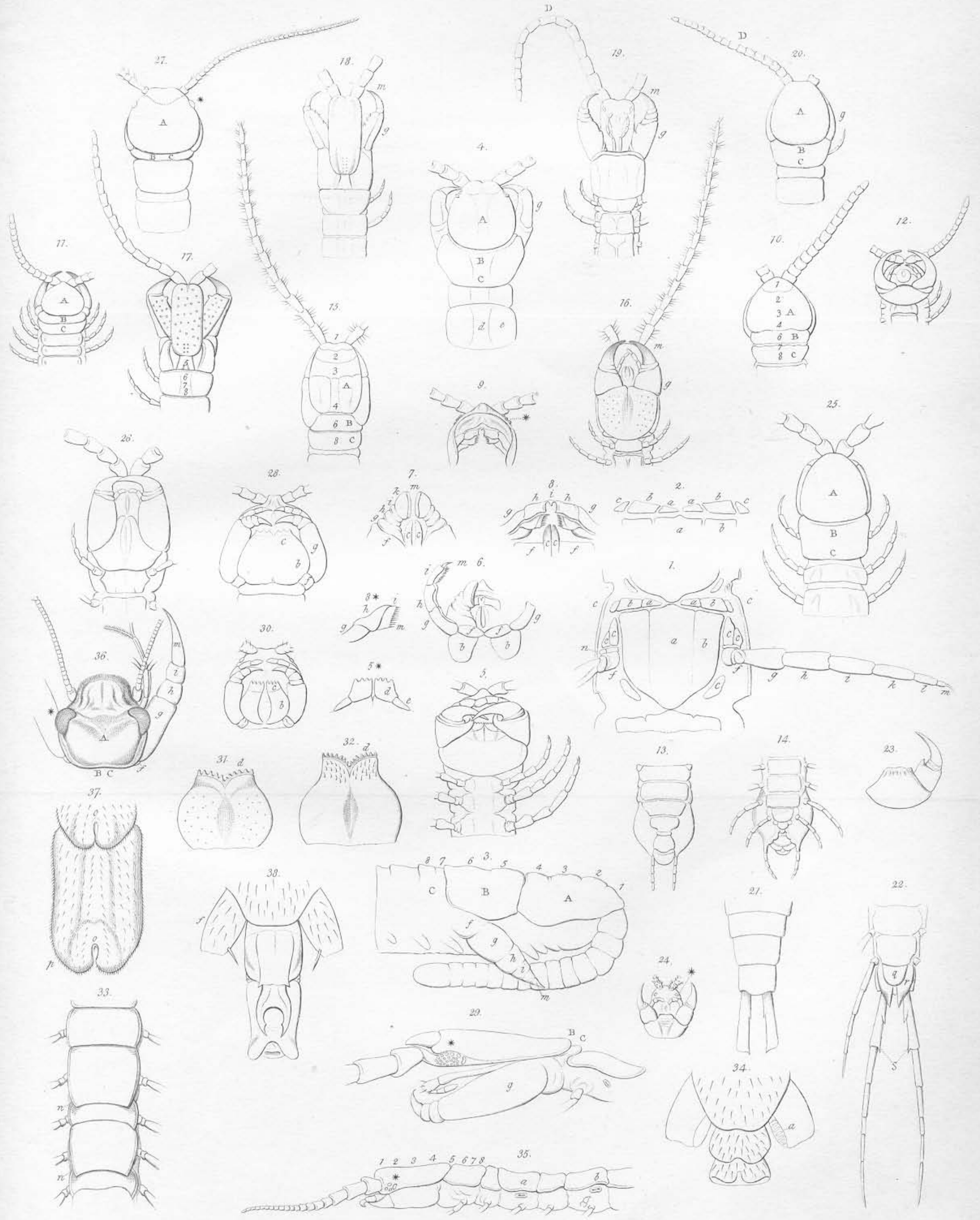